Modern Asian Studies 44, 5 (2010) pp. 1029-1051. @ Cambridge University Press 2009 doi:10.1017/S0026749X09990278 First published online 23 December 2009

\title{
Indonesia's Salafist Sufis ${ }^{1}$
}

\author{
JULIA DAY HOWELL \\ Griffith Asia Institute, Griffith University, \\ Nathan, Queensland 4I I I, Australia \\ Email:j.howell@griffith.edu.au
}

\begin{abstract}
Islam's devotional and mystical tradition, Sufism (tasawwuf), is commonly cast as antithetical to Salafi Islam. Self-identified 'Salafis', with their ideological roots in anti-liberal strands of twentieth-century modernist Islam, do commonly view Sufis as heretics propagating practices wrongly introduced into Islam centuries after the time of the pious ancestors (the Salaf). Yet reformist zeal that fixes on the singular importance of the Salaf (particularly the Prophet Muhammad and his principal companions) as models for correct piety can also be found amongst Sufis. This paper calls attention to the Salafist colouration of Sufism in two areas of popular culture: television preaching and the popular religious 'how-to' books and DVDs that make the preachers' messages available for purchase. It reprises the teachings of two of the best known Indonesian Muslim televangelists, 'Hamka' (b. 19o8, d. 1981) and M. Arifin Ilham (b. 1969), both of whom also happen to be champions of Sufism, and analyses the different rhetorical uses each has made of references to the 'Salaf' and the notion of 'Salafist' Islam.
\end{abstract}

\section{Introduction}

Islam's devotional and mystical tradition, Sufism (tasawwuf), is commonly cast as antithetical to Salafi Islam. Self-identified 'Salafis', with their ideological roots in anti-liberal strands of twentiethcentury modernist Islam, commonly view Sufis as heretics propagating practices wrongly introduced into Islam centuries after the time of the

1 The assistance of the Australian Research Council, which supported the research on which this paper is based with a Discovery grant, is acknowledged with appreciation. The author warmly thanks Ahmad Najib Burhani, who assisted with the interviews referenced in the text, as well as colleagues who kindly devoted their time to critiquing the text: Muhamad Ali, Harry Aveling, Michael Feener, Anthony Johns, Akh Muzakki, Merle Ricklefs and the journal's reviewers. Naturally, the responsibility for any remaining errors and shortcomings is entirely the author's. 
pious ancestors (the Salaf). Yet reformist zeal that fixes on the singular importance of the Salaf (particularly the Prophet Muhammad and his principal companions) as models for correct piety can also be found amongst Sufis. This was anticipated in the 'neo-Sufi' reform movement in Sufi orders (A. tariqa; I. tarekat) like the Naqsyabandiyyah prior to the twentieth century, ${ }^{2}$ and is becoming better known as a feature of certain contemporary Sufi movements in Asia Minor and South Asia. ${ }^{3}$ However, it is little known in Indonesia, and then only in connection with certain tariqa. ${ }^{4}$ Popular Sufi spirituality outside the tariqa in the later twentieth and early twenty-first centuries is instead known for its liberal and eclectic colouration and for the criticism it has attracted from Salafis and other scripturalist modernists. ${ }^{5}$

This paper calls attention to the Salafist colouration of Sufism in two areas of popular culture: television preaching and the popular religious 'how-to' books and DVDs that make the preachers' messages available for purchase and ongoing study. Specifically I focus on the teachings of two of the best known Indonesian Muslim televangelists, Haji Abdul Malik Karim Amrullah (commonly known by the acronym 'HAMKA'; b. 1908, d. 1981) and M. Arifin Ilham (b. 1969), both of whom also happen to be champions of Sufism. Hamka, a renowned scholar, is widely acknowledged as the first of the silverscreen celebrity preachers, having moved into that medium in the 1970s. Arifin Ilham is a current star. He was modestly successful off-screen in the late 1990s, and became famous on-screen after the

${ }^{2}$ Azyumardi Azra, The Origins of Islamic Reformism in Southeast Asia: Networks of MalayIndonesian and Middle Eastern 'Ulama' in the Seventeenth and Eighteenth Centuries (Crows Nest, NSW: Allen \& Unwin, 2004); Frederick De Jong and Bernd Radtke (eds.), Mysticism Contested: Thirteen Centuries of Controversies and Polemics (Leiden: Brill, 1999); and R.S. O'Fahey and Bernd Radtke, 'Neo-Sufism reconsidered', Der Islam, 70 (1993), pp. $5^{2-87}$.

3 Julia Day Howell and Martin van Bruinessen, 'Sufism and the "modern" in Islam', in Sufism and the 'Modern' in Islam, ed. by Martin van Bruinessen and Julia Day Howell (London: IB Tauris, 2007).

${ }^{4}$ Azra, The Origins of Islamic Reformism; Martin van Bruinessen, 'Controversies and polemics involving the Sufi orders in twentieth-century Indonesia', in Islamic Mysticism Contested: Thirteen Centuries of Controversies and Polemics, ed. by Frederick De Jong and Bernd Radtke (Leiden: Brill, 1999).

${ }^{5}$ Julia Day Howell, 'Muslims, the New Age and marginal religions in Indonesia: Changing meanings of religious pluralism', Social Compass, $5^{2}$ (2005), pp. 473493; Julia Day Howell, 'Modernity and Islamic spirituality in Indonesia's new Sufi networks', in Sufism and the 'Modern' in Islam, ed. by Bruinessen and Howell (London: IB Tauris, 2007); Julia Day Howell, 'Repackaging Sufism in urban Indonesia', ISIM Review, 19 (2007), pp. 22-23; and Alwi Shihab, Islam Sufistik: 'Islam Pertama' dan Pengaruhnya hingga Kini di Indonesia (Bandung: Mizan, 2001). 
turn of the twenty-first century when entertainment values eclipsed scholarly credentials in religious television broadcasting. Arifin is the creator of the phenomenon of the mega-mosque Zikir Akbar (broadcast religious services where thousands gather in the country's grandest and most beautiful mosques to chant soulful litanies) and of a spiritual development programme which he describes as 'Islam klasik (Salafiyah)' ('classic [Salafi] Islam'). ${ }^{6}$

Hamka, whose career began in the final years of the colonial period, decades before the advent of television in Indonesia, started his work of religious outreach via the print media. He was highly educated in the classical literature of Islam (first by his famous father, Haji Rasul, who helped to introduce Islamic modernism to their natal Minangkabau area of Sumatra, and then in a variety of reformist and traditionalist schools in Sumatra). He eventually made major contributions to Islamic scholarship. This was recognised in awards made to him of honorary doctorates, first by Al-Azhar University in $195^{8}$ and then by the University Kebangsaan Malaysia in 1974. However, in the early years of his life he worked as a journalist, popular writer and editor, and even as a novelist. It was at that time of his life when he wrote a series of magazine essays on the importance of spirituality ('kebatinan', 'kerohanian', 'tasauf' - all used interchangeably) ${ }^{7}$ to the life of a modern Muslim. Shortly thereafter, in 1939, these essays were gathered into a book entitled Tasauf Moderen ('Modern Sufism'), which has never been long out of print. That book made him one of the most important figures in the popularisation of Sufism amongst Indonesia's modernising elites.

Hamka, like his father, became a well-known activist in the modernist movement, joining the Muhammadiyah, a voluntary organisation founded in Java in 1912, to promote Islamic modernist ideas and education. Muhammadiyah, which became Indonesia's leading institutional vehicle of modernist reformism, was the source

\footnotetext{
${ }^{6}$ M. Arifin Ilham and Syamsul Yakin, Indonesia Berzikir (Depok: Intuisi Press, 2004), p. 38 .

7 As, for example, on p. 6 of Hamka's Perkembangan Tasauf dari Abad ke Abad [The Development of Sufism from Age to Age] (Jakarta: Pustaka Islam, 1962 [1952]). This is significant in light of later distinctions that developed in Indonesian religious discourse and law between kebatinan and kerohanian on the one hand, and tasawwuf on the other. The former became associated with eclectic mystical movements outside Islam, and tasawrouf came to be accepted (in large part through Hamka's influence) as properly part of Islam. See Julia Day Howell, 'Sufism and the Indonesian Islamic revival', Journal of Asian Studies, 6o (2001), pp. 701-729.
} 
of much strident criticism of Sufism for most of the twentieth century. Although this stance was not consolidated until the 1930s, from then until the mid-ı9os Muhammadiyah proscribed many supererogatory rituals associated with the Sufi tradition. ${ }^{8}$ Such practices, like the repetitive zikir litanies, were commonly used by traditionalist Muslims (i.e., those associated with the Nahdlatul Ulama $[\mathrm{NU}]$ organisation). Modernists branded them heterodox 'innovations' (bid'ah). Muhammadiyah also disapproved of the tariqa (Sufi orders), over which many NU clerics presided.

Hamka's championing of apparently opposing agendas (defending and popularising tasawwouf, while also promoting Islamic modernism through the Muhammadiyah) can be understood when we appreciate the depth and variety of his early education in classical Islamic scholarship $^{9}$ and his accomplishments as a mature scholar (as exemplified in his five volume Tafsir Al-Azhar [1967]), ${ }^{10}$ which were unparalleled in Indonesia in his time despite his late move into academia after a career in journalism. However, rather than investigating this feature of Hamka's personal biography, I propose to reprise Hamka's defence of a Salafist tasawwuf and compare it with the 'Islam klasik (Salafiyah)' put forth by Arifin Ilham, Hamka's distant successor on the silver screen and in popular print predication.

\section{Hamka's Salafist Sufism}

The enormous variety of self-styled Salafist movements notwithstanding, their core feature, as betokened by the name itself (derived from the Arabic word 'salaf', meaning 'predecessor' or 'ancestor'), is the special importance these movements assign to the example of the Prophet Muhammad, his companions and the second and third generations of the Prophet's followers. Their examples, as described in the Qur'an and Hadith, more than any later judgements in the classical schools of law and theology, are taken to be authoritative.

\footnotetext{
${ }^{8}$ Ahmad Najib Burhani, 'Revealing the neglected missions: Some comments on the Javanese elements of Muhammadiyah reformism', Studia Islamika (Jakarta), 12 (2005), pp. 101-130; Merle C. Ricklefs, Polarising Javanese Society: Islamic and Other Visions (c. I830-1930) (Singapore: NUS Press, 2007), p. 223; and Howell, 'Sufism and the Indonesian Islamic revival', p. 712.

${ }^{9}$ Cf. Peter Riddell, Islam and the Malay-Indonesian World. Transmission and Responses (London: Hurst, 2001), p. 216.

${ }^{10}$ Hamka, Tafsir Al-Azhar (Jakarta: Perbimbing Masa, 1967).
} 
Hamka, like his fellow modernists in Indonesia and elsewhere, devoted his scholarly labours to reassessing the Sunni heritage, including the classical schools of jurisprudence (figh), so that modern Muslims could clearly identify the true examples that the Prophet and other pious ancestors of the early days of the faith set for them.

Unlike most of his associates in the Muhammadiyah, ${ }^{11}$ who regarded tasawrouf as a late and corrupting foreign intrusion into proper Islamic practice, Hamka saw tasawrouf as part, indeed the core (inti), ${ }^{12}$ of authentic Islam with its roots in the devotional life of the Prophet himself. Thus, his major works on tasawrouf, Perkembangan Tasauf dari Abad Keabad ('The Development of Sufism from Age to Age') and Tasauf, Perkembangan dan Pemurniannnya ('Sufism, Development and Purification'), are structured around his understanding of the history of tasawrouf, beginning with the Prophet Muhammad's seclusion in the Hira Cave, where he had his first revelation. In Perkembangan Tasauf, ${ }^{13}$ he recollects Muhammad's practice (even long before that revelation) of going on retreat to such an isolated place every Ramadan. Hamka at once identifies the antecedents of several Sufi (kaum Shufijah) practices in Muhammad's withdrawal to mountain fastnesses and his activities there: first, the practice of khalwat (retreat, or temporary withdrawal from the concerns of everyday life), which is commonly practiced by Muslims, but especially by Sufis; and second, the elements of zuhud (living abstemiously to shift attention from material to spiritual concerns) which is one of the Sufi practices enjoined at the very beginning of the classical paths of spiritual development. At this point in Hamka's argument he does not introduce the term 'zuhud', but he does picture the Prophet Muhammad following a practice later identified as such. Thus he describes how the Prophet brought meagre provisions of

${ }^{11}$ Surveying attitudes towards tasawwouf amongst Indonesian modernists in the twentieth century, Alwi Shihab distinguishes between 'extremists' and 'moderates', the 'extremists' being those who consider tasawwuf in general and the Sufi orders, or tariqa, in particular to be late, heterodox intrusions (bid'ah) into Islam. See A. Shihab, Islam Sufistik: 'Islam Pertama' dan Pengaruhnya hingga Kini di Indonesia (Bandung: Mizan, 2001), p. 253. The 'moderates', in his terminology, are those who accept tasawrouf purged of certain practices. Hamka would be an example of a 'moderate'. The way Shihab labels these contrasting attitudes suggests that the blanket condemnation of tasawwuf by modernists was less common than guarded acceptance. That, however, is not evident in Muhammadiyah's official stances towards Sufi rituals for most of its history.

${ }^{12}$ Hamka, Perkembangan Tasauf dari Abad ke Abad, p. 192. (Also published under the title Tasauf, Perkembangan dan Pemurniannya [Sufism, Development and Purification].)

${ }^{13}$ Hamka, Perkembangan Tasauf, pp. 17-20. 
food and water with him to the cave and there did without the other comforts of civilization that he had left behind in the valley below.

Hamka himself explicitly links what Muhammad was doing in the Hira Cave when he received his first revelation with practices that latter-day Muslims identified with the Sufi tradition:

If we take careful note [of what Muhammad was doing] when [he] removed himself to the Hira Cave ... and then we compare [this] with the lives of the Sufis [ahli 2 tasauf] who came after [him], we can easily see the similarities in their lives and those of the Prophet. ${ }^{14}$

Immediately Hamka goes on to say that this is a recommendation for today's Muslims:

And, using [those] practices and endeavours and sensibilities, we can bring the path that we tread...into line with a pure spiritual life [such as theirs] ... ${ }^{15}$

Hamka further recounts canonical stories of the Prophet's everyday life, showing how he modelled the classic Sufi virtues of simplicity (zuhud), patience (sabar) and gratitude (syukur) even while leading his community and attending to his family. Hamka underlines the importance of these values to the Prophet himself by injecting here the story of the occasion when the Angel Gabriel appeared to him and posed the choice of being a prophet who is 'rich as King Solomon or one who suffers the deprivations of a Job'. ${ }^{16}$ Muhammad, we are told, answered:

... he would prefer to be hungry one day and full the next. So when he was hungry he would learn patience (sabar), and when he was full he would have occasion to give thanks to God (syukur). ${ }^{17}$

Even the Prophet's ritual observances, Hamka observed, in company with other Muslim scholars, modelled practices later associated with Sufis:

He wore very plain clothes, and ate only a slice of bread or a date accompanied by a swallow of water, and for his devotions, he woke in the middle of the night [to pray], and sometimes also cried while praying; all [this] is an ideal life that is much yearned for [amat dirindui] by Sufis [ahliz Tasauf] ${ }^{18}$

\footnotetext{
${ }^{14}$ Hamka, Perkembangan Tasauf, p. 21.

${ }^{15}$ Hamka, Perkembangan Tasauf, p. 21.

${ }^{16}$ Hamka, Perkembangan Tasauf, p. 25.

${ }^{17}$ Hamka, Perkembangan Tasauf, p. 25.

${ }^{18}$ Hamka, Perkembangan Tasauf, p. 25.
} 
Moving on to stories about the spiritual character cultivated by the Prophet's companions (Sahabat), Hamka tells us that they followed the Prophet's example in living lives marked by 'plain living, abstemiousness, humility, and having simple wants' ('sederhana, wara', tawadu', dan zuhud'). ${ }^{19}$ He supports this with illustrative anecdotes about Abu Bakar, Umar bin Khattab, Usman bin 'Affan and Ali bin Abi Thalib. He summarises the spiritual qualities cultivated by the companions by observing that their lives were based on two fundamentals, 'patience' (sabar) and 'acceptance' (ridha) ${ }^{20}$ Again, these are qualities that followers of various Sufi paths in later eras have striven to strengthen in their character as part of their basic spiritual training. ${ }^{21}$

Hamka further points out that in the time of the Prophet Muhammad there was a cluster of particularly dedicated followers (we might say renunciates) who lived in quarters next to the mosque. These 'Ahlus Suffah' had no families and no money and were supported by the rest of the community. ${ }^{22}$ While one might wonder if these were mere charity cases, Hamka presents them as examples of people striving for spiritual virtue, although through more extreme abstentions than practiced by the Prophet himself, who counselled moderation as well as occasional austerities.

In summary, Hamka shows, through his survey of the lives of the Salaf, that practices now commonly identified with tasawrouf helped constitute the spiritual lives (hidup kerohanian) of Muhammad and the other 'pious ancestors'. These practices include spiritual disciplines (in the narrow sense of techniques) like khalwat (retreat), waking for devotions in the middle of the night (tahajjud) ${ }^{23}$ and fasting while on retreat, as well as ethical disciplines undertaken as the groundwork for Sufi mystical realisation, such as zuhud, sabar, wara', tawadu' and ridha.

${ }^{19}$ Hamka, Perkembangan Tasauf, p. 27.

${ }^{20}$ Hamka, Perkembangan Tasauf, p. 29.

${ }^{21}$ Thus, in one of the most common Sufi schema of graded spiritual striving, the aspirant is pictured as moving from syariah (conforming to the religious rules set for the whole ummah), to tariqa (where specific disciplines like zuhud are undertaken to perfect the spiritual virtues and to refocus attention upon the Creator), to hakekat (the opening of awareness onto a transformed understanding of God's being and presence), to makrifat (the ultimate mystical realisation).

${ }^{22}$ Hamka, Perkembangan Tasauf, p. 29.

${ }^{23}$ This word was not actually used in Hamka's recounting of the spiritual lives of the Salaf, although he described the practice. 
Significantly, he does not mention zikir ${ }^{24}$ in his recounting of the spiritual lives of the Salaf. Later, when discussing tasawwuf in the time of $\mathrm{Al}$ Ghazali, he does refer approvingly to zikir as 'remembering, or saying [to oneself the name of] Allah' ('ingat, atau menjebut Allah') to keep God constantly in mind. ${ }^{25}$ Without belabouring the point, Hamka thus implies by omission that ritualised zikir practice (wherein short phrases from the Qur'an are repeated in large multiples of hundreds or more) does not have any authorising presence in the lives of the Salaf and therefore should be abjured as a heretical invention (bid'ah).

These spiritual disciplines and ethical practices (minus ritualised zikir), Hamka believed, are taken up naturally by pious Muslims as they read the Qur'an and contemplate Hadith (the stories of the Salaf) with sincere devotion. ${ }^{26}$ In the holy book and authoritative stories, sincere Muslim readers can see for themselves the examples that the Salaf set and will be inspired to imitate them as far as possible.

Over the history of Islam, however, he deemed that certain excesses and perversions (like ritualised zikir) emerged in what became the tasawrouf tradition. ${ }^{27}$ One of his key tasks was to identify those perversions so that they could be excised and tasawwu restored to its 'original condition' (as per his title Mengembalikan Tasaufke Pangkalnya). Then, he hoped, Sufism could assume its appropriate place in the lives of modern Muslims. Thus, Perkembangan Tasauf and Mengembalikan Tasauf describe an arc of historical development of Sufism from a few simple practices in the time of the Prophet Muhammad through their early positive elaboration in an emerging body of Sufi devotions and metaphysics, but then, by the fourteenth century, a decline set in. From that time, under the weight of polytheistic practices in many of the then emerging Sufi orders (tariqa), and due to the pernicious influence of certain Sufi philosophers (such as Ibn Arabi and others who subscribed to his wahdat al wujud metaphysics), Hamka believed Sufism began to sink into widespread deviance. ${ }^{28}$

${ }^{24}$ Lit. remembrance; more broadly, constant recollection of God in everyday life or in ritual litanies.

${ }^{25}$ Hamka, Perkembangan Tasauf, p. 125.

${ }^{26}$ Hamka, Perkembangan Tasauf, p. 64.

${ }^{27}$ Hamka is at pains to point out that tasawrouf became a named tradition only in the second-century Hijrah, just like fiqh (jurisprudence), which took several centuries to coalesce into a named discipline. See Perkembangan Tasauf, p. 75 .

${ }^{28}$ Hamka does acknowledge that by the fourteenth century, 'all sorts of foreign influences' had come into Islam and contributed to the corruption of tasawwouf (see 
It is evident that it is the role of the Sufi adept as teacher of esoteric knowledge that gives rise to the excesses which Hamka condemned. The spiritual masters or syekh of the Sufi orders initiated their students into knowledge of specific devotional techniques thought to open up realms of spiritual experience otherwise not generally open to people, and also acted as guides in those uncharted regions. This carried the hazard of the teacher slipping into syirik (polytheism) by, in effect, putting himself up as someone who had become closer to God than others, a 'second to God'. Thus, Hamka found that certain masters of the Sufi orders of the thirteenth to fourteenth centuries encouraged their followers to believe that they or their predecessors had become wali keramat (i.e., saints who had acquired supernatural powers through their extraordinary experiences of closeness to God). Accordingly, he thought, such wali allowed people to commit the heresy of 'worshipping' them and asking for blessings at the graves of their illuminated predecessors. ${ }^{29}$ Hamka also condemned the practice of rabithah, whereby the spiritual aspirant visualises the initiating master of the order during ritualised zikir to facilitate the aspirant's experience of moving into the presence of God. ${ }^{30}$

It is notable, however, that Hamka did not want to dissuade his fellow Muslims from cultivating a rich inner life and seeking to 'lift the veils' of material existence that hide realms of extraordinary knowing of the divine. He even specifically refers repeatedly to makrifat (the highest level of spiritual knowing in the graded Sufi ascent to gnosis). ${ }^{31}$ His objection was only to certain heretical practices commonly encouraged by Sufi orders and to the idea that the tariqa and their syekh were necessary to such spiritual unfoldment. In his view, the spiritual practices (latihan jiwa $)^{32}$ modelled by the Prophet Muhammad and his immediate successors (as above) could be, and are better, practiced simply as an ordinary Muslim, without any connection to a syekh or tariqa.

His Tasauf Moderen was written to help people do that. It is a kind of do-it-yourself guide to personal and spiritual development. In it he expands on the spiritual disciplines of the Salaf, showing how in modern society one might strive to live modestly, for example,

Perkembangan Tasauf, p. 55), but he did not accept that tasawwuf itself was a latter-day foreign import into Islam (see Perkembangan Tasauf, pp. 33, 54).

${ }^{29}$ Hamka, Perkembangan Tasauf, p. 187.

${ }^{30}$ Hamka, Perkembangan Tasauf, p. 64.

${ }^{31}$ For example, Hamka, Perkembangan Tasauf, pp. 19, 22-23.

${ }^{32}$ Hamka, Perkembangan Tasauf, p. 125. 
remembering the importance of zuhud, and yet work hard to provide for one's family and contribute to society, accepting both the riches that may come from that and also life's trials, knowing undue focus on worldly concerns clouds perception of God's guidance and closeness. In Tasauf Moderen Hamka thus models practices of independent ethical reflection (like those undertaken in the tariqa stage of a classic path of Sufi spiritual ascent from syariah to tariqa to hakikat to the culmination, makrifat). These practices are meant to promote personal moral integrity and to exercise the sensitivities necessary to developing a more subtle awareness of God's guiding presence.

In Perkembangan Tasauf, which post-dates TasaufModeren by more than a decade, Hamka also makes clear the importance to spiritual growth of both (1) meditation (which appears, from his writing, to be a mental exercise of refocusing a person's attention from material concerns to the Creator in a dedicated period of quiet), and (2) emotionally charged contemplation, specifically of the glories of God, either in retreat or in the course of everyday life. ${ }^{33} \mathrm{He}$ also quite explicitly asserts that such spiritual exercises (both ascetic and meditative) can give rise to 'strange experiences', as they did for Muhammad and his companions. Writing for his 'modern' readers, he admits that 'some people would say that the Salaf were just crazy [gila]', ${ }^{34}$ but no, he says, extraordinary things did happen to them. Interestingly, he airs the controversy amongst Muslim scholars over what actually happened on Muhammad's miraculous flight to the 'farthest mosque' and heaven, the Isra' and Mi'radj: Was Muhammad transported in the physical body or in some spiritual condition? Either way, he judged, it was a miracle. ${ }^{35}$ And in any case, Hamka seems to be encouraging the reader to accept that cultivating a proper Muslim spiritual life the way orthodox Sufis have can open up a realm of esoteric experience. He explains how this is possible:

The Great Soul [djiwa besar] approaches God [Tuhan] and receives a fragment of the Light of guidance [Nur hidayat] from the Lord. As such, the soul is hardly bound by time or shackled by space. For it there lies open the secret, and the veil of the whole world [jilbab seluruh alam] [is lifted], through the grace and

${ }^{33}$ Hamka, Perkembangan Tasauf, pp. 19-23.

${ }^{34}$ Hamka, Perkembangan Tasauf, p. 22.

35 This is quite close to a phenomenological interpretation, which would focus on the reality of the experience of heavenly transport, if not of the heavens witnessed. See Hamka, Perkembangan Tasauf, p. 23. 
permission of God ... This is one example set by the people who have followed Sufi (mystical) Islam [Tasauf (mistik) Islam]! ${ }^{36}$

Since Hamka is promoting Sufism, we might think that there is nothing remarkable in his including references to mystical experiences, that is, to intense, 'non-ordinary' or 'altered state' experiences. However, it must be remembered that the Muslim modernist movement (in which he participated) was intensely concerned to reconstruct Islam as a 'rational' religion. Modernists wanted Islam to be free not only of 'superstitions' (khurafat), so labelled because the beliefs or practices were understood to be foreign 'inventions' (bid'ah) inconsistent with orthodox precedents in the faith, but they wanted the faith to be free of more egregious cases of 'superstition', so labelled because they violated the plausibility tests of modern science. In short, Muslim modernists were sensitive to the rhetoric, widespread in the colonial context, of 'superstition' as 'irrational' beliefs not supported by empirical investigation, and thus the mark of 'inferior' peoples.

Hamka very much shared the Muslim modernist agenda of renovating the faith to meet the new demands of societies that are increasingly driven by science-based technological achievements. Thus he opens the first chapter of Perkembangan Tasauf with an appeal to his readers to take cognisance of the new world in which they are living: "The age of the atom", he begins, "that is the name that people give to our times'. ${ }^{37}$ In that book and in his other writing on tasawrouf he strongly endorsed the exercise of independent, reasoned judgement. ${ }^{38}$ Indeed his defence of tasawrouf called on readers to consider a reasoned defence of Sufism based on historical evidence. His Tasauf Moderen, likewise, mounts a soundly reasoned case for going beyond mere conformity to community religious norms to a subtle examination of personal motivation. Ethical discernment requires careful, reasoned judgement and honest assessment. But, as he argued in Perkembangan Tasauf, the modern world faces unprecedented dangers

${ }^{36}$ Hamka, Perkembangan Tasauf, p. 23.

${ }^{37}$ Hamka, Perkembangan Tasauf, p. 9 .

38 This echoes Hamka's lectures and writing on Qur'anic exegesis, where he encourages modern Muslims to use well-informed critical reason to form their own independent judgements about the meanings of the holy text. However, the level of skills he considered necessary for this was beyond the level of most of his readers, raising questions as to how autonomous they could actually be in religious matters. See Riddell, Islam and the Malay-Indonesian World, p. 269. 
(playing on his opening reference to atomic energy technology); people feel overwhelmed by them and by the rapid pace of change. And, referencing passages from Kant, Voltaire and Nietzche as well as the Egyptian Muslim Husain Haikal Pasja, he says modern people are also coming to realise that materialism is not really satisfying; a new interest in spirituality (kerohanian) is evident. ${ }^{39}$

That Hamka recommends his modified tasawwuf as a remedy for modern materialism suggests that he judged scripturalist Islam (i.e., the narrowly dogmatic and legalistic Islam of his fellow Muslim modernists) insufficient sustenance in the modern world. In Perkembangan Tasauf, he explains why he believes this is the case, arguing that rule-focused Islam calls upon only 'the brain' (otak) and 'logic' (logika), neglecting the esoteric faculty of spiritual feeling (rasa, zauq). ${ }^{40}$ Without cultivating the inner spiritual faculty, people find it difficult to resist the materialism of the modern world, and also the vices of the body that have always been with us. ${ }^{41}$ Using classic Sufi images, he explains that spiritual exercises 'cleanse the heart [hati]' ('hati' being the principal esoteric centre of the body in tasawwuf) and enable the believer not only to offer intellectual assent to his faith, but to feel 'close to God'. ${ }^{42}$ In Mengembalikan Tasaufke Pangkalnya he goes further and asserts that the pinnacle of Islamic spirituality, makrifat (mystical gnosis), is an experience of profound unity of being in a special sense: not of union with God and becoming one with His being (as for Ibn 'Arabi, whose wahdat al wujud metaphysics ${ }^{43}$ Hamka condemns as heretical), but a mystical sense of unity with all of God's creation. From that, he argues, flows a sense of the common humanity of all people, regardless of national or sectarian differences. This, he said, could help realise what his country so greatly needed: real 'humanitarianism' (peri-kemanusiaan, the second of Indonesia's famous Panca Sila or Five Principles), to which the Preamble to the country's 1945 Constitution was committed. ${ }^{44}$

${ }^{39}$ Hamka, Perkembangan Tasauf, pp. 9-11.

${ }^{40}$ Hamka, Perkembangan Tasauf, pp. 105, 125.

${ }^{41}$ Hamka, Perkembangan Tasauf, p. 125.

${ }^{42}$ Hamka, Perkembangan Tasauf, p. 125.

${ }^{43}$ Wahdat al wujud is commonly translated as 'unity of being', and suggests a monist conception of ultimate reality.

${ }^{44}$ Hamka, Mengembalikan Tasauf Kepangkalnja [Restoring Sufism to Its Original Condition] (Jakarta: Panjimas, 1972), pp. 53-54. 


\section{Arifin Ilham's 'Islam Klasik Salafiyyah'}

Arifin Ilham rose to stellar national fame in 2001, more than a decade after the passing away of his illustrious predecessor Hamka. An invitation in Ramadan of that year to lead prayers with extended zikir in Jakarta's beautiful At-Tin Mosque before a live audience of 7,ooo and a home television audience of millions launched him into the world of celebrity televangelism. ${ }^{45}$ As more invitations followed to conduct services, including collective zikir at mosques with capacities of many thousands plus nationwide television coverage, he rapidly became famous for his 'Zikir Akbar' ('Great Zikir').

But Arifin was not from the traditionalist Muslim (NU) community which commonly appended zikir litanies to the obligatory prayers (shalat wajib), and which supported tasawwuf learning and the tariqa. His father was a Muslim modernist active in the Muhammadiyah organisation in Banjarmasin, South Kalimantan, and he did his early schooling in Muhammadiyah schools. ${ }^{46} \mathrm{He}$ even acquired some common modernist prejudices against Muslims who practice extended zikir, as revealed in a story told by Mintarja ${ }^{47}$ :

One day, as Arifin told it, he and his father happened to pass a mosque where people used to recite the zikir litanies out loud together. Arifin said to his father, 'They're already in hell. Doing it so loud and all, they're making a great scene.' 'Umm, yes ..., I agree', said his father, 'they're wasting their time'.

Nevertheless, in his early teens he was taken with the notion of doing the rest of his secondary schooling in a traditionalist religious school, a pesantren. But he told his father he didn't want to go to the oldfashioned kind 'where the students go around in sarongs'; he wanted a pesantren 'where they wear a tie and jacket'. ${ }^{48}$ His father acquiesced and sent him to a progressive pesantren in Jakarta for high school. Like Hamka, then, Arifin gained some familiarity with classical Islamic

45 Tb. Ace Hasan Syadzily, Arifin Ilham, Dai Kota Penabur Kedamaian Jiwa [Arifin Ilham, the City Preacher Who Spreads Spiritual Tranquility] (Jakarta: Hikmah, $2005)$, p. 36.

${ }_{46}$ Achmad Nawawi Mujtaba (ed.), Menggapai Kenikmatan Zikir: Fenomena Muhammad Arifin Ilham dan Majelis Zikir Az-Zikra [Attaining the Bliss of Zikir: The Phenomenon of Muhammad Arifin Ilham and Majelis Zikir Az-Zikra] (Jakarta: Hikmah, 2004), p. 35; and Endang Mintarja, Arifin Ilham, Tarikat, Zikir, dan Muhammadiyah [Arifin Ilham, the Sufi Orders, Zikir and Muhammadiyah] (Jakarta: Hikmah, 2004), p. 39ff.

${ }^{47}$ Mujtaba (ed.), Menggapai Kenikmatan Zikir, p. 41 .

${ }^{48}$ Mintarja, Arifin Ilham, p. 40. 
scholarship, even if he never probed that mine to anything like the same depth or breadth.

Instead Arifin cultivated a talent he discovered in high school for religious oratory, winning contests both at home and in Singapore. Then, after finishing a bachelor's degree in International Relations from Universitas Nasional (Jakarta) in 1995 , he drew on those talents to make a modest living out of preaching.

His pesantren experience notwithstanding, in his early years as a dai (preacher) Arifin remained opposed to any 'Sufi' elaborations of the required prayers (like zikir) and conducted his religious outreach entirely through sermonising. All that changed, however, after he was bitten in 1997 by a poisonous snake. During his perilous recovery he had a series of dreams in which he was called to a mosque to lead zikir and saved his fellow Muslims from the snares of Satan. ${ }^{49}$ Thereafter he began leading services with collective zikir and extended muraqabah at his local mosque. In the muraqabah he guided those assembled in reflection on their sins and in repentance, often moving many people to tears.

That format became the basis for his 'Zikir Akbar', the grand collective zikir (zikir berjama'ah), performed since 2001 by gatherings of thousands and viewed nationwide by many more on television. The somewhat distinctive way he conducts public zikir is also called 'Zikir Taubat', signalling the importance of soulful repentance such as he models in the muraqabah following the zikir litanies. 'Zikir Akbar' and 'Zikir Taubat' have now become something like brands associated with a broader programme of spiritual development that Arifin has elaborated, and (because of the controversial nature of extended zikir, and especially collective zikir) defended.$^{50}$ Like other celebrity preachers, Arifin has promoted his programme for spiritual development not only in his sermons and talks, but also in his popular books, videos and DVDs.

In Indonesia Berzikir, ${ }^{51}$ Arifin (with his co-author Yakin) makes it clear that the zikir litanies are urgently needed by modern Muslims who find scripturalist Islam 'dry', echoing Hamka's worries about scripturalism. Performing zikir litanies, Arifin claims, enables Muslims to sense a closeness to God, adding the richness of spiritual experience

${ }^{49}$ Mujtaba (ed.), Menggapai Kenikmatan Zikir, p. 41.

${ }^{50}$ For example, see M. Arifin Ilham, Hakikat Zikir, Jalan Taat Menuju Allah, [The True Essence of Zikir, Road of obedience to Allah] rev. ed. (Depok: Intuisi Press, 2004), p. 30 .

${ }^{51}$ Ilham and Yakin, Indonesia Berzikir, p. 33. 
to the obligatory prayers. ${ }^{52}$ Without this, he says, people are likely to get caught up in 'materialism', ${ }^{53}$ a concern Hamka also had, although Hamka recommended unstructured, quietistic meditation and contemplation rather than zikir litanies for this purpose. ${ }^{54}$ Again, in contrast to Hamka, Arifin goes on to picture the West as responsible for spreading 'sekularisasi' (here meaning something like societywide atheism) along with materialism. Weakened by materialism and intimidated by Western science and philosophies, he fears Muslims are easy prey to materialist critiques of religion, like those of Karl Marx. ${ }^{55}$ Indonesian society is therefore in urgent danger. ${ }^{56}$ For this reason, Arifin and his associates have propounded not only a programme of personal spiritual development, but also a 'vision and mission' for the nation: 'Indonesia Berzikir' ('Indonesia Joins in Zikir'), set out in his eponymous book. ${ }^{57}$

Even though Arifin, unlike Hamka, has rehabilitated ritualised and collective zikir, he joins Hamka in arguing the specifically Salafist, and therefore orthodox, character of (proper) tasawwuf. To do this, he, like Hamka, distinguishes latter-day tasawwuf practices that he considers to have firm precedents in the lives of the pious ancestors from those that do not (generally, those associated with the tariqa, like praying to saints [wali] and using the syekh as intermediaries). Thus, Arifin distinguishes 'Salafi Sufism' ('sufi Salafi') from 'Sunni Sufism' ('sufi Sunni'). 'Sunni Sufism' is the Sufism of the traditionalist ulama who, modernist Muslims commonly judge, have allowed pure traditions to be infiltrated with foreign heretical practices. ${ }^{58}$ On this basis he confidently asserts that his programme of Sufi-inspired spiritual development is 'classic (Salafist) Islam' ('Islam klasik [Salafiyah]'). ${ }^{59}$

In my reading, however, Arifin Ilham's Salafism has a distinctly different tone to that of Hamka. This becomes evident not only, or even primarily, in Arifin's defence of ritualised and collective zikir, for which Hamka found no justification in the lives of the Salaf. Rather,

${ }^{52}$ Ilham and Yakin, Indonesia Berzikir, p. 115.

${ }^{53}$ Ilham and Yakin, Indonesia Berzikir, p. 33.

${ }^{54}$ Note, however, that some Sufi orders have a silent zikir practice (zikir khofi) that might be thought similar to the quiet turning to God that Hamka recommended. The zikir khofi, however, at least starts by inwardly repeating a litany, even if it moves into some more profound quiet as the practice continues.

${ }^{55}$ Ilham, Hakikat Zikir, Jalan Taat, pp. 74-77.

${ }^{56}$ Ilham and Yakin, Indonesia Berzikir, pp. 35, $103 \mathrm{ff}$.

${ }^{57}$ Ilham and Yakin, Indonesia Berzikir, p. 16.

${ }^{58}$ Ilham and Yakin, Indonesia Berzikir, pp. 29-32.

${ }^{59}$ Ilham and Yakin, Indonesia Berzikir, p. 38. 
the difference lies in the benefits Arifin attributes to zikir and the kind of spiritual introspection he promotes. These, I suggest, imply an exclusivist and homogenous collectivism that contrasts with the glimmers of universalism that here and there break through Hamka's representation of tasawwuf. The way Arifin institutionalises his zikir movement and approves coercion, legal and otherwise, in 'defence' of the Muslim community's morals, lends further support to this interpretation.

This is evident in the headline value that Arifin attaches to zikir: it reinforces 'obedience'. He signals this in the title of his 2004 bestseller, Hakikat Zikir, Jalan Taat Menuju Allah ('The True Essence of Zikir, Road of Obedience to Allah'). The book's foreword ${ }^{60}$ sums up what readers will get from reading it. It will help Muslims 'lift the quality of their zikir' so that it can 'hit the target, namely creating an individual who is obedient [and] who [along with other such practitioners] will give birth to a society that is obedient and pious before Allah'.61

Reading through, we find Arifin recommending the classic starting points of Sufi spiritual development (i.e., following the rules of Islam and working on the Sufi virtues, which 'cleanse the heart'), followed by the use of ritualised zikir. Zikir, we learn, deepens the cleansing process and gives the practitioner access to the pleasurable 'focus' or 'absorption' (khusuk) that is the essence of prayer. ${ }^{62}$ The deep spiritual gratification (kenikmatan) of zikir (also described in Mujtaba's Menggapai Kenikmatan Zikir) then motivates further striving to be a truly obedient and pious Muslim. ${ }^{63}$

While these steps of Sufi spiritual development and the spiritual gratification that flows from it are fairly standard and similar to what Hamka presented, what stands out is his checklist approach to spiritual accomplishment and its rewards. In his books he provides only minimal elaboration of what constitutes virtue, other than to list the standard qualities for which one strives on the Sufi path. ${ }^{64}$ The rewards for diligent zikir practice are even set out in his Indonesia

${ }^{60}$ Didin Hafidhuddin, 'Kata pengantar', in Ilham, Hakikat Zikir, Jalan Taat, pp. 11-12.

${ }^{61}$ Hafidhuddin, 'Kata pengantar', p. 12.

62 Ilham, Hakikat Zikir, Jalan Taat, pp. 19-2 1, 27-29.

${ }^{63}$ Ilham, Hakikat Zikir, Jalan Taat, pp. 2 1-22.

${ }^{64}$ For example, in his three-page discussion of the stages of Sufi practice in Hakikat Zikir, he gives this list of qualities that the practitioner should cultivate: ikhlas, istiqamah, syukur, sabar tawakkal, dermawan, penyayang, jujur, amanah, zuhud and tauhid), 
Berzikir in a numbered list of 60 boons, starting with 'repelling Satan and smashing his powers', and moving on through other spiritual benefits, such as 'inspiring love of God', 'opening the doors of gnosis' and also more tangible blessings, such as 'attracting good fortune'. Some of these, apparently, come in greater measure to diligent zikir practitioners than to those who merely pray or practice good works. ${ }^{65}$ This formulaic approach to salvation and divine favours, with rewards and punishments for following certain rules as to the type and quantity of ritual performance, contrasts with Hamka's concern with more individualised character formation.

Likewise, the muraqabah Arifin leads after the collective zikir in his mosque services is a review by listing of possible failures of obedience, for which forgiveness must be sought. Even though Arifin (reflecting his modernist background) places great emphasis on understanding just what is said through the whole ritual (translating every Arabic word into Indonesian) ${ }^{66}$, and he frequently stresses in his books the necessity of 'introspeksi' and 'internalisasi' of the underlying or true meaning (hakikat) of all prayers, he does little to encourage openended reflection on what might actually constitute virtue in a given situation. Also, he links these spiritual refinements only to Muslim spiritual life, without acknowledging that Western philosophical and religious traditions have inspired people to cultivate similar virtues, as Hamka does.

In contrast, Hamka wrote an entire book (TasaufModeren) setting out a modern practice of Sufi spiritual discernment, carefully examining how it is possible to distort spiritual values by overdoing them or using a supposed virtue or even a legal judgement on permissible behaviour as an excuse for one's own selfish desires or lack of initiative. The applicability of a rule or virtue, the reader learns from Hamka, should be systematically examined in the context of his or her own character and social situation.

Hamka was also much concerned with the practical psychology of moral improvement and actually engaged his reader's interest at the outset by appealing to a universal human interest in happiness (bahagia). In fact, the text of Tasauf Moderen appeared originally as

noting however, that they are actually not just Sufi but the 'soul of every Muslim person' (ruh dari setiap pribadi Muslim). See Ilham, Hakikat Zikir, Jalan Taat, p. 20.

${ }^{65}$ The list of 60 boons is drawn with acknowledgement from Ibn al-Qayyim's list of 'over one hundred' benefits of zikir. See Ilham and Yakin, Indonesia Berzikir, pp. 66-7o.

${ }^{66}$ Syadzily, Arifin Ilham, Dai Kota, p. 96. 
serialised essays on 'happiness' in the Muslim magazine Pedoman Masjarakat, and the initial problem posed in this modern manual of Sufi practice is 'What constitutes real happiness?' He goes on to explore answers to this question that have been given by Western philosophers and men of letters, as well as by Muslim scholars and the Prophet himself. All are aligned, he shows, in acknowledging that material goods alone are not sufficient to happiness (recognising the common spiritual sensibilities of people everywhere - our common humanity), and then demonstrating the particular wisdom of Islam in this matter, and especially of Islam's latterly neglected path of spiritual perfection, tasawwuf. Even in setting out this path, he uses categories of experience that are recognisable by people of all major intellectual and religious traditions. Happiness will come from developing keutamaan otak (intellectual excellence) together with keutamaan budi (excellence of character) or perangi utama (a superior character). ${ }^{67}$ The tasawwuf traditions for cultivating self-restraint and ethical refinement are then cast as the means to developing excellence of character (keutamaan budi).

It could be said, then, that Hamka's tasawwuf is less narrowly sectarian and more individualistic, in the sense that it places heavy responsibility on the individual Muslim both to consider the newly expanded range of legal interpretations that modernists were opening up in the twentieth century (argued elsewhere, as in his Tafsir AlAzhar $)^{68}$ and to assess when and in what way individual Muslims can best realise the spiritual values underlying that law in each situation (argued in Tasauf Moderen). Each person does this in private reflection and study. Also, Hamka's tasawwuf is, if not inclusivist, at least respectful of spiritual striving in other traditions and frequently refers to insights from their great thinkers, side by side with those of Muslim scholars, to support his own points.

Arifin Ilham, in contrast, is more collectivist, viewing religious law as, on the whole, clear and settled already by the community, and what constitutes virtue as largely unproblematic. Everyone can be held to the one standard, and the community rightly has an interest in doing so. Thus Arifin stresses in Indonesia Berzikir ${ }^{69}$ that the Sunnah (or authoritative models for behaviour set by the Prophet) does not change over time, and he supplies copious examples of the punishments God

${ }^{67}$ Hamka, Tasauf Moderen [Modern Sufism] (Singapore: Pustaka Nasional Pte Ltd, 1997 [1939]), p. 117.

${ }_{68}$ Hamka, Tafsir Al-Azhar.

${ }^{69}$ Ilham and Yakin, Indonesia Berzikir, p. 48. 
has visited upon whole communities that throughout history and today have gone against His will. Supernatural sanctions are invoked to motivate conformity elsewhere as well. People who do not accept the message of the Prophet Muhammad are cast as dupes of Satan, ${ }^{70}$ and those Muslims who are lacking in piety must be reached and drawn into Arifin's 'Indonesia Berzikir' ('Indonesia Joins in Zikir') movement. 'There is no other way', Arifin insists in his book Indonesia Berzikir, 'Indonesia indeed has to zikir'. ${ }^{71}$ This follows on his observation that both the leadership of the country and the people of Indonesia have turned their backs on God's gifts and can expect punishments such as visited upon the ancients. As the title to a later chapter ('Indonesia Berzikir Sebagai Pintu Gerbang Keinsyafan Kolektif') tells us, the zikir movement is the gate to a 'collective awakening' that will enable the country to overcome all kinds of ills, from its leadership crisis and widespread immorality to natural disasters.

Arifin sees this movement developing naturally, as people experience the ethereal enjoyments of zikir practice and their families see this and follow suit; then their other relatives and friends will take up the practice, and so on, spreading the movement across the society. ${ }^{72}$ The collective impulse also finds institutional expression in Arifin's Al-Zikra Zikir Council (Majelis Zikir Al-Zikra). Majelis zikir are something of a new phenomenon in Indonesia ${ }^{73}$ resembling tariqa but more open and, notionally at least, formed around the members' common interests in practicing zikir together, rather than around the charismatic ties radiating out from a syekh. Majelis Zikir AlZikra coordinates the activities of Arifin's ministry and promotes the 'Indonesia Berzikir' movement. It has also taken steps to give literally a concrete form to Arifin's collectivist aspirations: the Council is opening a residential community in South Jakarta. Normative pressures for close conformity to the Al-Zikra ritual regimen in that community are evident in the plan to require residents to do their prayers and zikir practice together in the community's mosque before and after work. Given long and unpredictable commuting times from that part of the city, that will require extraordinary commitment.

${ }^{70}$ Ilham, Hakikat Zikir, Jalan Taat, p. 39.

${ }^{71}$ Ilham and Yakin, Indonesia Berzikir, p. 22.

${ }^{72}$ Mujtaba (ed.), Menggapai Kenikmatan Zikir, p. $63 \mathrm{ff}$.

73 Arif Zamhari, Rituals of Islamic Spirituality: A Study of Majlis Dhikr Groups in East Java (PhD Dissertation, Australian National University, Canberra, 2007). 
Hamka never called for such a community of 'true believers', distinguishable from the rest of the Muslim and Indonesian community by their more fervent, correct piety. One wonders whether he would, like some contemporary critics of Arifin's majelis zikir, judge it as a tariqa in new guise, and worry that the promotion of Arifin as a celebrity has not made him (denials notwithstanding) into a guru whose pronouncements are taken, simplistically, as final authority. ${ }^{74}$

Arifin and the Al-Zikra Zikir Council disavow any personal political aspirations for Arifin. As Mujtaba put it, this is a 'piety movement' (gerakan takwa), not a political movement; it is not 'high politics but sky politics' ('Bukan high politic tapi sky politic' [sic]). ${ }^{75}$ Nonetheless, Arifin has acknowledged ${ }^{76}$ that he is in sympathy with those who are working in the political sphere to make Indonesia a syariah-based Islamic state. He also voiced his ready approval of the Front Pembela Islam's (Islamic Defenders Front or FPI) violent assaults on nightclubs and other activities judged offensive to Islam. ${ }^{77}$

${ }^{74}$ Arifin has had to address such criticisms from his contemporaries. Defending his Majelis Zikir Al-Zikra, he told a zikir akbar audience of thousands in Jakarta's Istiqlal Mosque, 'This is not a tariqa but ordinary zikir (zikir biasa) for lay people (orang

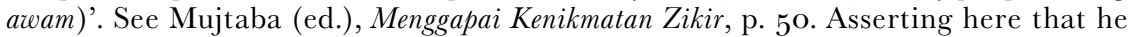
is but a lay person (like the members of the audience) is a way of saying that he does not claim to have spiritual authorisation (ijaza) (such as the syekh of a tariqa would have) to initiate disciples, and he is not calling his audiences to form any bond of loyalty to him or submit to his authority, such as would be the case in a tariqa. His close associate Endang Mintarja devotes several chapters of his book on Arifin and the movement to clarifying the distinction. Arifin routinely has the demeanour of an ordinary santri or pious person identified with the strict Muslim community, and refuses any special deference to him as a religious teacher. He has also established a council of advisors of extraordinary scope and distinction (including the nationally renowned moderate scholar Quraish Shihab at one end of the spectrum, and the notorious radical Abu Bakar Ba'asyir at the other) from whom he says he 'seeks correction'. Nonetheless, he has been charged with promoting a 'personality cult' (kultus individu), with his overwrought visage featuring on the covers of his books and DVDs, even overshadowing on one book cover the name of Allah. See Abu Amsaka, Koreksi Dzikir Jama'ah M. Arifin Ilham (Jakarta: Darul Falah, 2003), pp. 16o-166.

${ }^{75}$ Mujtaba (ed.), Menggapai Kenikmatan Zikir, p. 146.

${ }^{76}$ Interview with M. Arifin Ilham in Depok, 2006.

77 Note also that on 22 June 2008, in one of his Zikir Akbar at the Istiqlal Mosque, Arifin offered prayers of support for the leader of the Islamic Defenders Front (FPI), Habib Rizieq Shibab, who had been jailed in connection with the FPI's 1 June 2008 violent assault on a peaceful celebration of Indonesia's freedom of religion led by the AKKBB at the National Monument, Jakarta. See Ihsanul Muttaqien, 'Jakarta berzikir di usianya ke-481' in Wikimu.com News, 24 June 2008, http://www.wikimu.com/News/DisplayNews.aspx?id=9141 (accessed 26 June 2008). 


\section{Conclusions}

This reprise of Hamka's and Arifin Ilham's Sufism helps us to see that in Indonesia, as elsewhere in the world today, the Sufi tradition is being reworked in Salafist variants, and this is specifically for modern Muslims. Both these proselytisers (one famous for his scholarship and popular writing and latterly as a pioneer of television preaching, and the other a mega-star televangelist who effectively promotes his spiritual development programme through books and DVDs) have arisen from the Muslim modernist community associated with the prominent voluntary organisation Muhammadiyah. Yet both have championed Sufism against substantial resistance from within that movement. Their Salafist construction of what they consider genuine, unadulterated tasawwuf is meant to answer modernist charges of heterodoxy that have been current in the Muhammadiyah movement for most of the twentieth century and persist today outside that movement as well.

These cases show that Salafist variants of Sufism have been successfully marketed through the mass media, including television. Like other new-style Muslim televangelists in Indonesia and the Middle East (both Salafist-Sufi and anti-Sufi Salafist), Hamka and Arifin seek to inflame religious recommitment through witnessing to gratifying spiritual experiences of God's closeness and guidance that can come with intensified piety. ${ }^{78}$ Unlike the new-style Middle Eastern televangelists whose Salafism condemns Sufi practices, however, Hamka and Arifin actually promote some tasawwuf spiritual exercises as means to uncovering a well of inner spiritual life. Arifin goes farther than Hamka in recommending not only disciplines of (moderated) asceticism and ethical striving and mindfulness of God, but also ritualised 'remembrance' (zikir), using lengthy litanies in private prayer and communal worship.

Not only do Hamka and Arifin authorise a different range of Sufi spiritual exercises, but the tone of their Salafist representations of Sufism is rather different. Hamka's is more individualistic, in keeping with his sense that modern Muslims must exercise a high degree of autonomy and personal responsibility in their religious lives, as elsewhere. The exercises that he models at length in TasaufModeren are practices of individual ethical discernment; these open out the reader's

${ }^{78}$ Julia Day Howell, 'Modulations of active piety: Professors and televangelists as promoters of Indonesian "Sufisme", in Expressing Islam: Religious Life and Politics in Indonesia, ed. by Greg Fealy and Sally White (Singapore: ISEAS Press, 2008). 
understanding to many subtle differences in the circumstances in which patience, abstemious living, etc., might, or might not, improve one's character and thereby increase one's spiritual sensitivities. He emphasises that the work of spiritual discernment is complex and requires cultivation of the intellect (as well as faith and trust in God) to develop 'the highest character'.

Arifin's emphasis is more collectivist. Not only does he authorise communal ritualised zikir, but his approach to zikir practice and its rewards is more formulaic. While he does insist that each individual Muslim should understand the Arabic words used in Islamic rituals and 'internalise' the meaning of the ritual, he quickly skirts past problems of judgement in practicing the Sufi ethical disciplines. Similarly, Arifin continually promotes the value of the spiritual experiences that come to those who follow his programme of Sufi exercises, not just as gratifying and so as motivators for more spiritual practice, but as spurs to 'obedience'. Arifin's 'hell fire and damnation' preaching (such as in his stories of God's collective punishments of the disobedient and of Satan leading people to reject the true faith) further creates the tone of exclusivist collectivism in his ministry.

Although Hamka as a public figure famously promoted exclusivist practices like refraining from wishing Christians 'Merry Christmas', his major works on tasawwuf counsel against overweening sectarian pride, and respectfully recognise spiritual striving in many different religious and cultural traditions. The fact that he urges upon modern Muslims a way to deepen their piety (tasawwuf) using the nonsectarian vocabulary of human 'happiness' (bahagia) and 'excellence of character' (keutamaan budi) is also suggestive of a positive engagement with Western thought, rather than a hostile defensiveness which becomes more characteristic of Salafi movements in the later twentieth and twenty-first centuries.

It is probably significant that Hamka began deploying the language of keutamaan budi in the 1930s, when the civil servant class of the Dutch East Indies, the priyayi, had become alienated from their Islamic heritage and transferred their esteem to 'the budi and kawruh of the Dutch-transmitted age of European progress' and to the pre-Islamic culture of Java. ${ }^{79}$ As we have seen, up to the 1930s, there was a substantial priyayi presence in the Muhammadiyah, the modernist organisation with which Hamka was associated. The language of

${ }^{79}$ Ricklefs, Polarising Javanese Society, p. 212. 
'noble character' and his use of Western philosophy as well as Islamic scholarship to present the value of tasawwuf demonstrated that the Javanists were not the only ones who could appeal to cultural cosmopolitans. Such an audience also exists today, alongside more defensive and exclusivist Salafis.

Finally, Hamka's extraordinary description of the highest of the spiritual states, makrifat, as an experience of unity, not with God, but with all of God's creation, and thus a real experience of peri-kemanusiaan (humanity beyond the bounds of nation or religion), again suggests at least a qualified spiritual universalism. Remembering his absolute commitment to the truth of the Islamic revelation and his lifelong efforts to teach proper practice of the faith, perhaps it is appropriate to recognise Hamka's tasawrouf as approximating the traditionalist perennialism of a Syed Hussein Nasr, insofar as it appears to recognise the universality of mystical unfoldment, but seeks to guide Muslims along their own straight path to it. 